\title{
Towards ecological and social impact through collaborative governance of a seascape of marine protected areas in Honduras
}

D A N IEL S TEA D M A N

\begin{abstract}
Protecting marine biodiversity and ensuring sustainable use through a seascape approach is becoming increasingly widespread in response to the ecological, social and institutional challenges of scaling ocean management. A seascape approach means clustering spatial management measures (marine protected areas) based around the principles of ecological connectivity, and developing or enhancing collaborative governance networks of relevant stakeholders (managers, community groups, non-governmental organizations) based around the principles of social connectivity. As with other large-scale approaches to marine management, there is minimal evidence of long-term impact in seascapes. This study uses a theory-based, participatory impact evaluation to assess perceived changes attributed to the Atlántida seascape in Honduras (initiated in 2015), encompassing three well-established marine protected areas and the nonlegally managed waters between them. Using an adapted most significant change method, 15 interviews with a representative subset of seascape stakeholders yielded 165 stories of change, the majority (88\%) of which were positive. Enhanced social capital, associated with cross-sectoral collaboration, inter-site conflict resolution and shared learning, was the most consistently expressed thematic change (32\% of stories). Although most stories were expressed as activity- or output-related changes, a small proportion (18\%) were causally linked to broader outcomes or impact around increased fish and flagship species abundance as well as interconnected well-being benefits for people. Although minimal (and occasionally attributed to prior initiatives that were enhanced by the seascape approach), this impact evidence tentatively links seascapes to recent related research around the effectiveness of appropriately scaled, ecosystembased and collaboratively governed marine management that balances strict protection with sustainable use.
\end{abstract}

Keywords Atlántida, Bay Islands, Honduras, collaborative governance, marine protected areas, most significant change, MPA networks, seascapes

Supplementary material for this article is available at doi.org/10.1017/So030605320001155

DANiel Steadman (Corresponding author, (D) orcid.org/0000-0002-6420-7815) Fauna \& Flora International, The David Attenborough Building, Pembroke Street, Cambridge, CB2 3QZ, UK. E-mail daniel.steadman@fauna-flora.org

Received 24 February 2020. Revision requested 17 June 2020.

Accepted 14 October 2020. First published online 26 January 2021.

\section{Introduction}

The ocean is an increasingly crowded space. Competing 1 and accelerating uses of marine resources have resulted in more ambitious approaches to ocean governance and spatial protection of marine biodiversity at various scales (Jouffray et al., 2020). At national level, states are increasingly implementing governance systems that are more ambitious than individual marine protected areas, for example, through marine spatial planning initiatives (Lester et al., 2013), network development (Grorurd-Colvert et al., 2014) and spatial licensing systems for fishing, such as managed access (Foley, 2012). As marine network initiatives scale to encompass more sites and responsible institutions, the challenges of human and institutional capacity increase (De Santo, 2013; Gill et al., 2017).

Governance of individual and networked protected areas has increasingly involved the participation of more stakeholders (i.e. beyond solely government) and the development of a broad range of collaborative governance arrangements (Dearden et al., 2005). Although evidence exists that collaborative governance leads to greater likelihood of conservation success, such effects are also highly influenced by national contexts (Waylen et al., 2010). Sustainable success may depend on 'a broad set of social activities that re-enforce one another in a virtuous cycle' (Kossmann et al., 2016, p. 16), conditions that are not always achieved. For collaborative governance at a network/national level to succeed, stakeholders may have to harmonize participatory arrangements (e.g. developed at local or regional scales) with government-led top-down systems (Solandt et al., 2014).

One potential mechanism for equitable, effective marine conservation at scale is the concept of the seascape, defined as a 'model to manage large, multiple-use marine areas in which government authorities, private organizations, and other stakeholders cooperate to conserve the diversity and abundance of marine life and to promote human well-being' (Bensted-Smith \& Kirkman, 2010, p. i). Seascape models have been developed in Latin America and South-east Asia and aim to be as ecosystem-based as other largescale marine management approaches (e.g. Large Marine Ecosystems, Marine Ecoregions) but with a greater focus on 'sustainable, multi-level governance' (ibid., p. iii).

In 2015, international NGO Fauna \& Flora International (FFI) and a consortium of five Honduran NGOs (Fundación Cuero-Y-Salado, Fundación Cayos Cochinos, Fundación Islas de la Bahia, La Asociación Pro Comunidades 
Turísticas de Honduras and Centro Estudios Marinos) designed a project focused on collaborative marine governance across the Atlántida seascape on the Atlantic coast of Honduras (known in Spanish as the paisaje marino). The project proposed that a collaborative governance model across the Atlántida seascape was key to achieving these organizations' intended long-term impact (i.e. change outside the scope of the project) namely that 'The Honduran section of Mesoamerican Reef and associated marine habitat and species are protected and sustainably managed, while participating coastal communities enjoy improved livelihoods and food security, and reduced vulnerability' (Fauna \& Flora International, 2015, p. 18). The overall objective of this project, referred to as its outcome, was integrated, collaborative management established across an 800,000 ha seascape, encompassing three Marine Protected Areas, thereby protecting critical habitats and species, making fisheries more sustainable, and improving livelihoods and food security of 1,00o people' (ibid., p. 18). This outcome was to be achieved through the completion of 40 activities (actions taken by the six NGOs and wider partners) in support of five outputs (deliverables providing the necessary conditions to achieve the outcome). These outputs were focused on enhancing (1) marine management, (2) compliance and enforcement, (3) social capital, (4) human capital, and (5) the marine evidence base (i.e. of species and habitat distribution) across the seascape (Fig. 1).

This study used a theory-based approach to impact evaluation (Woodhouse et al., 2016) to assess the extent to which this project's outcome was achieved, to identify any evidence of longer-term impact and to contextualize these results in the wider collaborative marine governance literature. Given the profusion of sites and organizations involved in the project, an adapted version of the most significant change participatory interview method was used to capture the perceptions of the individuals and organizations involved. This method involves the collection of stories from those involved in the fieldwork (Davies \& Dart, 2005) and has been used as a monitoring and evaluation tool to facilitate inclusive project reflection, learning and adaptation in diverse disciplines, including conservation (Wilder \& Walpole, 2008), development (Kraft \& Prytherch, 2016) and government policy delivery (Rabie \& Burger, 2019).

\section{Study area}

The Atlántida seascape is not a legally recognized management entity, but it aims to build on and integrate the statutory management regimes of three formal (legally designated) marine protected areas within it. The designated sites in the Atlántida seascape comprise one coastal site (Cuero-Y-Salado Wildlife Refuge, designated in 1987), and two island sites: Utila Island, within the wider Bay Islands Marine National Park, and Cayos Cochinos Marine
National Monument (designated respectively in 2013 and 2003). As with all protected areas in Honduras, site-level collaborative governance is well-established; each site has an NGO as a co-manager working under a legal agreement with both central and municipal governments. The comanagement history of these marine protected areas is complex and has been affected by ambiguous island ownership, ineffective decentralization and disputes over fisheries access (Bown et al., 2013), leading to conflicts between NGO co-managers and communities, and perceptions of overbearing management (Loperena, 2016).

The Atlántida seascape is a spatial clustering of these three sites as well as the non-legally protected waters between them, which are referred to as area gris or the grey area (Fig. 2). Recognizing past challenges as well as the interdependencies between management, ecological and social systems, the intention behind the Atlántida seascape is for an evolving network of organizations, which includes local government bodies, NGOs and small-scale fisheries organizations, to informally and collaboratively govern this area. This new governance model principally encompasses three newly-created (i.e. through the evaluated project) interinstitutional collaborative bodies with specific mandates (but with much overlap in membership and responsibilities; Table 1).

\section{Methods}

\section{Method selection}

The opportunity to undertake this study arose through a requirement of project funding from the UK government's Darwin Initiative (grant 23-028) for a final evaluation. Fauna \& Flora International adopts a causal pathway approach to project design and impact evaluation (Kapos et al., 2009) and uses the theory of change method to describe how and why change is expected to happen in a particular context (Fig. 1). Utilizing the causal pathway terminology defined in Woodhouse et al. (2016), this evaluation aimed to test the theory of how (and if) the seascape project's activities and outputs led to the achievement of its outcome and whether any evidence exists of longer-term impact.

In addition to drawing on theory-based approaches, the evaluation design was also driven by the need to make data collection participatory and to 'open studies to the voices of those most affected by a project in a way not possible using more conventional methods' (Chambers, 2009, p. 243). As outlined in Woodhouse et al. (2016, p. 22), participatory evaluation methods have the dual benefit of encouraging iterative, collaborative and adaptive project management (i.e. through shared lesson learning) and being driven by 'perceptions of intervention beneficiaries', thereby requiring minimal baselines or counterfactuals. Such methods are 


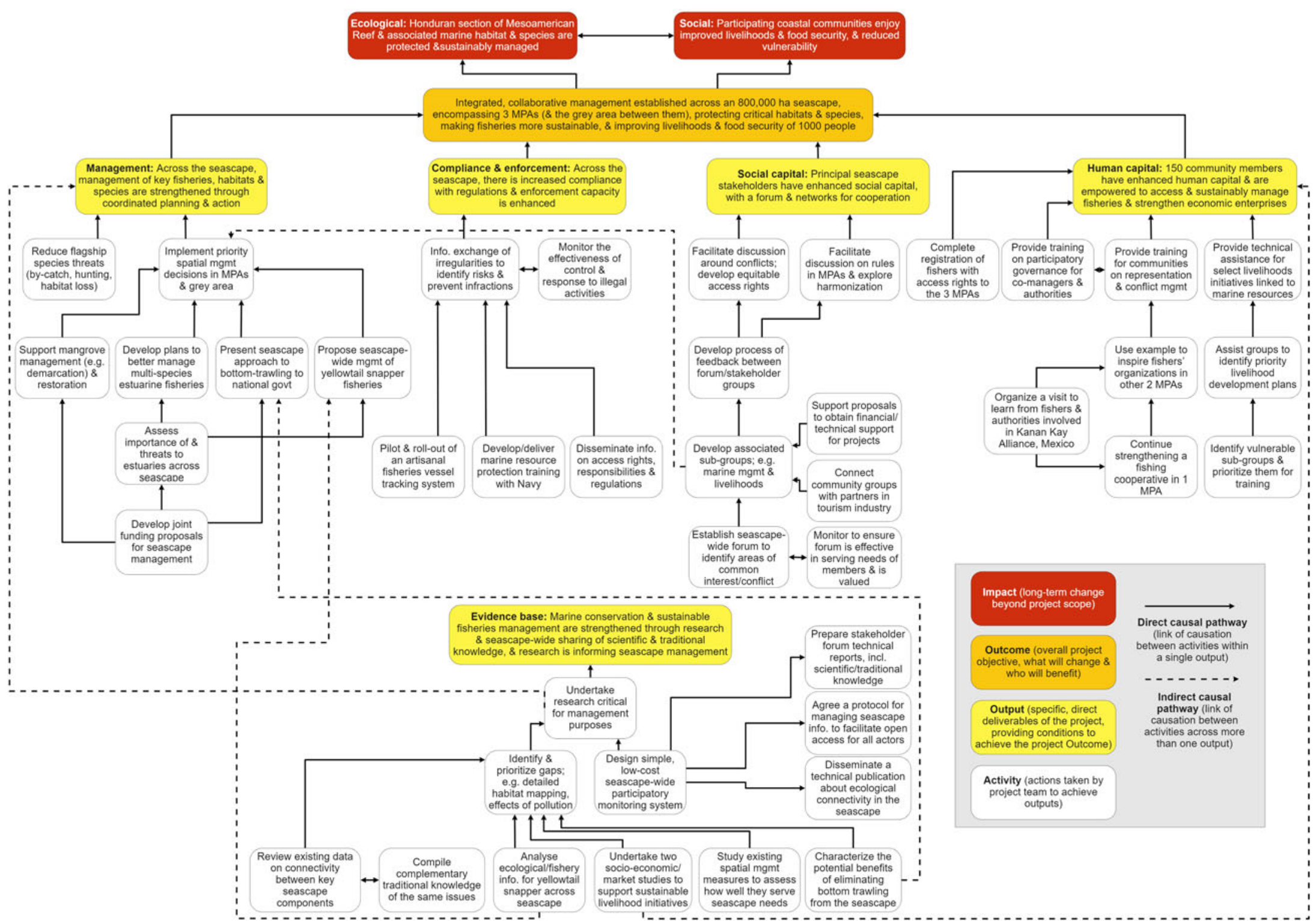

FIG. 1 Theory of change for the Atlántida seascape project showing causal pathways between activities and outputs and overall outcome (as well as longer-term impact). 


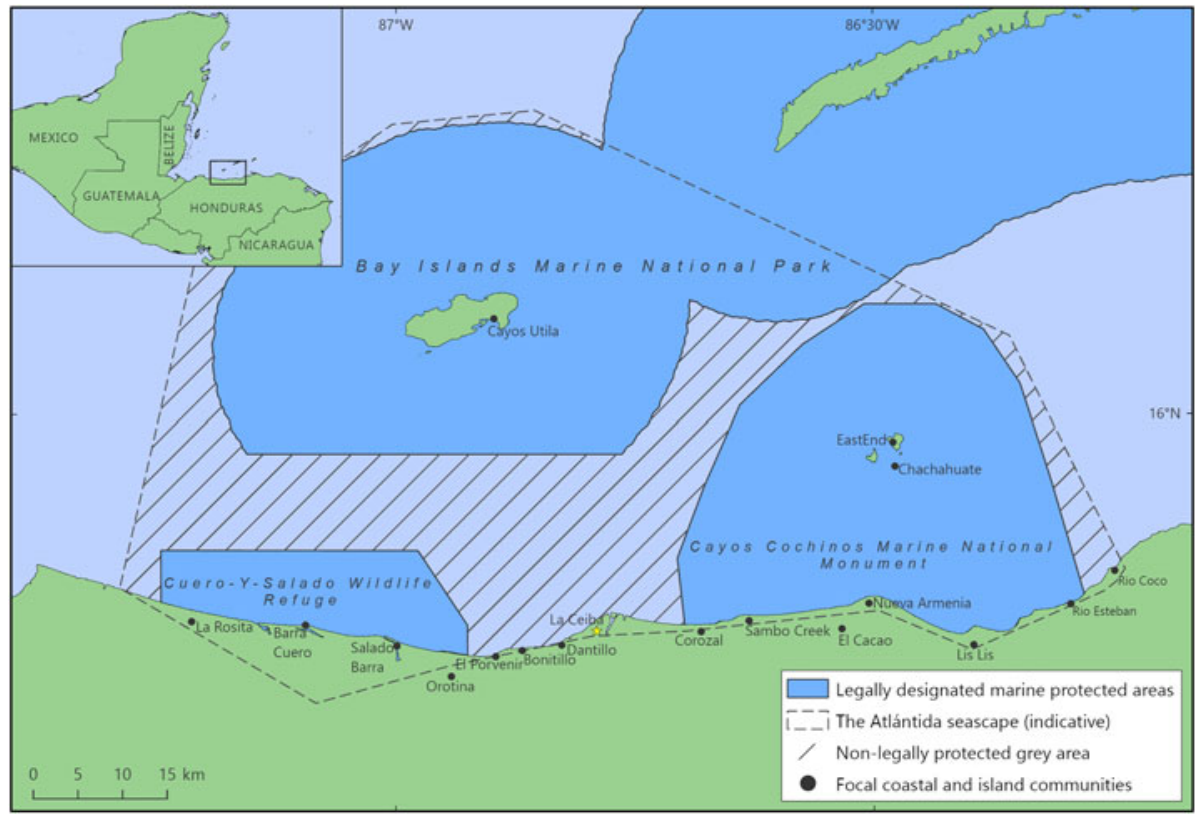

FIG. 2 The Atlántida seascape, made up of three marine protected areas and the grey area between them. The seascape boundary has no legal status and is presented indicatively.

TABle 1 Collaborative bodies established within the Atlántida seascape (Fig. 2).

\begin{tabular}{|c|c|c|c|}
\hline $\begin{array}{l}\text { Collaborative } \\
\text { body }\end{array}$ & $\begin{array}{l}\text { First } \\
\text { meeting }\end{array}$ & Organizations & Responsibilities \\
\hline $\begin{array}{l}\text { Fishers' } \\
\text { Roundtable }\end{array}$ & 2016 & $\begin{array}{l}17 \text { (fisher associations from nine } \\
\text { communities either within the three sites } \\
\text { or in the area gris) }\end{array}$ & $\begin{array}{l}\text { Developing livelihoods opportunities for members; } \\
\text { developing seascape-wide fisheries regulations; agreeing } \\
\text { basis for resolving fisheries conflicts }\end{array}$ \\
\hline $\begin{array}{l}\text { Seascape } \\
\text { Committee }\end{array}$ & 2018 & $\begin{array}{l}31 \text { (co-managers, fisher associations, } \\
\text { municipalities, NGOs \& headed by central } \\
\text { government) }\end{array}$ & $\begin{array}{l}\text { Collaborative development of regulations for the areas } \\
\text { between marine protected areas; management of } \\
\text { seascape-wide fish resources; addressing threats originat- } \\
\text { ing on land }\end{array}$ \\
\hline Seascape Forum & 2018 & $\begin{array}{l}\text { c. } 60 \text { (Fishers' Roundtable members, } \\
\text { Committee members, other organizations } \\
\text { in seascape) }\end{array}$ & $\begin{array}{l}\text { Exchange of information \& learning about seascape issues; } \\
\text { functions as a kind of congress; development of informal } \\
\text { commitments to collaborate }\end{array}$ \\
\hline
\end{tabular}

therefore suited to evaluations led by implementing organizations (i.e. via an 'action research approach, which uses research as part of the intervention itself) but must also be used carefully in attributing impact to interventions and adjusting for bias (ibid., p. 23).

Fauna \& Flora International chose the Most Significant Change method as a means of evaluating the seascape project in a manner consistent with a theory-based, participatory and action research-driven approach. It has been described as a method that is best suited to project evaluation with 'a short time frame, multiple sites, intangible complex outcomes and a focus on lesson learning' (ibid., p. 47). As defined by Davies \& Dart (2005), the method comprises multiple steps that involve defining the parameters of the study, collecting significant change stories/ data, selecting the most significant of those, feeding back/ verifying/reanalysing selected stories and finally revising the data collection system (if the method is being used to analyse change over time). Stories are elicited by asking open-ended, non-leading questions.

For this study, the principal question was: 'What are the most significant changes you have experienced [if interviewee was aware of the project] through the seascape project? [if not aware] in the past 3-5 years?' Where additional clarity or explanation was needed for answers, follow-up questions such as 'What is the significance of that story/event [to you]?' were also posed.

Interviewees were selected by the FFI team administering the grant on the basis that they or their organization played some form of operational role in the Atlántida seascape or were a potential beneficiary of project activities (Supplementary Material 1). Although all interviewees played some role in the project (therefore involving some inherent selection bias), selection was driven primarily by the need to be spatially representative and include individuals focused on each site within the Atlántida seascape 
TABLE 2 Organizations contributing to collaborative governance in the Atlántida seascape by category, with breakdown of organizations interviewed in this study.

\begin{tabular}{|c|c|c|c|c|c|}
\hline \multirow[b]{2}{*}{ Organization category } & \multicolumn{3}{|c|}{ Total members of seascape collaborative bodies } & \multicolumn{2}{|l|}{ Organizations interviewed } \\
\hline & $\begin{array}{l}\text { Seascape } \\
\text { Forum }\end{array}$ & $\begin{array}{l}\text { Seascape } \\
\text { Committee }\end{array}$ & $\begin{array}{l}\text { Fishers' } \\
\text { Roundtable }\end{array}$ & Names & Total \\
\hline National government & 15 & 6 & & $\begin{array}{l}\text { Instituto Nacional de Conservación y } \\
\text { Desarrollo Forestal (ICF) }\end{array}$ & 1 \\
\hline Local government & 11 & 9 & & $\begin{array}{l}\text { Unidad Municipal de Ambiente (UMA), } \\
\text { El Porvenir } \\
\text { Unidad Municipal de Ambiente (UMA), } \\
\text { Utila }\end{array}$ & 2 \\
\hline $\begin{array}{l}\text { Community group } \\
\text { (small-scale fisheries) }\end{array}$ & 10 & 6 & 9 & $\begin{array}{l}\text { Asociación de Pescadores de Santa Ana } \\
\text { (ApeSantA) } \\
\text { Asociación de Pescadores de La Rosita y } \\
\text { Cuero y Salado (APROCUS) } \\
\text { Comision de Pescadores de los Cayitos de } \\
\text { Utila (CSnapper) }\end{array}$ & 3 \\
\hline NGO (non co-manager) & 8 & 4 & & $\begin{array}{l}\text { La Asociacion Pro Comunidades Turistica } \\
\text { de Honduras (LARECOTURH) } \\
\text { Centro de Estudios Marinos (CEM) }\end{array}$ & 2 \\
\hline NGO (co-manager) & 7 & 5 & 1 & $\begin{array}{l}\text { Fundación Cayos Cochinos (FCC) } \\
\text { Fundación Cuero y Salado (FUCSA) } \\
\text { Fundación Islas de le Bahia (FIB) }\end{array}$ & 3 \\
\hline $\begin{array}{l}\text { Community group } \\
\text { (non small-scale fisheries) }\end{array}$ & 3 & & & Comite de Turismo, Boca del Toro & 1 \\
\hline Private sector & 2 & & & $\begin{array}{l}\text { Camara de Turismo de La Ceiba } \\
\text { (CTLCEiba) }\end{array}$ & 1 \\
\hline Academia & 2 & 1 & & $\begin{array}{l}\text { Centro Universitario Regional del Litoral } \\
\text { Atlántico (CURLA) }\end{array}$ & 1 \\
\hline Trade association & 1 & & & - & - \\
\hline $\begin{array}{c}\text { Intergovernmental } \\
\text { organization }\end{array}$ & 1 & & & - & - \\
\hline Total & 60 & 31 & 10 & & 14 \\
\hline
\end{tabular}

(including the grey area). Organizations included national NGOs (some co-managers, some not), municipal government bodies, national government bodies and small-scale fisheries organizations/associations (Table 2). Interviewees represented 14 organizations in total, comprising $45 \%$ of the organizations represented in the most operational collaborative body (the Seascape Committee, 31 organizations) and eight of the 10 focal sectors involved across all three bodies. I conducted the interviews in my capacity as a member of FFI's Conservation Science \& Design team who was not involved in directly administering the Darwin grant.

\section{Data collection}

A total of nearly 14 hours of interviews were conducted with 15 interviewees, either in the largest coastal city in the Atlántida seascape (La Ceiba) or on Utila Island (within the Bay Islands Marine National Park), during 30 April4 May 2019. Before an interview started, an initial introduction was given to explain the purpose of the study, the basic premise of the method, the role of the study author (i.e. as a semi-independent evaluator, not involved in managing the project or the Darwin grant), how the interviewee's responses would be used and, finally, asking the interviewee to indicate their consent to the process (see Supplementary Material 2 for the full interview opening statement and Supplementary Material 3 for my positionality/background statement). It was explained that, subject to their agreement, interviews would last up to 1 hour, but were not strictly timed. Interviews were conducted in English or Spanish, according to the interviewee's preference (see Supplementary Material 1 for the language used in each interview). When interviews took place in Spanish, they were conducted with a translator present. All interviews were recorded, with video.

Interviews began with the principal question described in the previous section, after which open-ended follow-up questions were posed to help interviewees articulate the significance of particular anecdotes or observations. Once a given story had been fully described, the principal question was repeated to elicit further responses. 


\section{Data analysis}

Prior to the formal analysis of assembled stories (i.e. their organization into a coherent framework), the most significant change method involves the collaborative process of story selection by the project team and interview participants, in which stories are ranked and voted on to support validation and verification.

In this study, this stage was adapted, partly because of time constraints and partly because of the evaluation's focus on reconciling stories with the project's theory of change (rather than assembling an entirely new framework). Instead of a formal selection process, staff members from FFI's five NGO partners were invited to a 1-day workshop in La Ceiba on 2 May 2019 (midway through data collection) to validate stories collected up to that time and to reflect on implications for the project. This exercise was conceived primarily as a means of enabling the project's implementing organizations to incorporate the first pieces of story evidence adaptively into future planning (rather than a formal, structured means of evaluating all stories). No formal analysis or results arising from this session are presented here.

Rather, to support analysis, interview footage was watched by FFI staff who observed and summarized stories within interviews, also noting their start points and key quotes. To evaluate alignment with the project's intended changes, each story was then categorized according to whether it described a generic change analogous to an activity, output, outcome or impact and to which of the project's intended outputs it most obviously related. Stories were also categorized by whether changes were expressed positively or negatively (binary) and whether they were attributable to the project (three-point scale: wholly, partly or not attributable).

Finally, to identify synergies between stories, they were assigned thematic codes (Gibbs, 2007; Armborst, 2017), facilitating the creation of a layer of themes. This process provided a means of inferring what interviewees meant in their statements; i.e. 'getting underneath what a person is saying to try to truly understand the world from his or her perspective' (Sutton \& Austin, 2015, p. 228). Given this approach requires subjective analysis, a brief consideration of my background (i.e. world view, experiences and priorities; Reason \& Bradbury, 2008) is provided in Supplementary Material 3.

\section{Results}

Through the 15 interviews, 165 significant change stories were identified, with a mean of $11 \pm \mathrm{SD}_{4}$ per interviewee. The majority of stories $(145,88 \%)$ were expressed as positive changes and $142(86 \%)$ were either wholly or partly attributable to the project. Stories predominantly described changes analogous to activities $(66,40 \%)$ or outputs $(70,42 \%)$, with far fewer analogous to outcomes $(22,13 \%)$ or impact $(7,4 \%)$. Of the four intended output areas of the project, stories were largely focused on changes related to social capital $(52,32 \%)$, human capital $(36,22 \%)$ and management $(32,19 \%)$; fewer stories focused on the marine evidence base $(8,5 \%)$ or compliance/enforcement $(7,4 \%)$. The 30 changes analogous to outcomes or impact were not aligned to specific output areas.

Stories were coded into 43 themes. The distribution of these themes and their alignment with project output areas are shown in Fig. 3 and dominant themes (i.e. those represented by five or more stories) are shown in Table 3. Summarized representation of specific stories, organized by project output area, is provided below, along with consideration of broader changes related to project outcome and broader impact.

\section{Social capital}

This output area ('The principal seascape stakeholders have enhanced social capital, with a forum and networks for cooperation on participatory marine management, fisheries, ecotourism and other priority development issues which they may identify'; Fauna \& Flora International, 2015, p. 24) aligned with the most stories $(52,32 \%)$ and was raised by 12 of the 15 interviewees ( $80 \%)$. Stories aligned to this output were largely related to the development of the three collaborative bodies and to the various activities associated with these bodies. The most prevalent themes were 'collaborative governance mechanisms broke down institutional barriers' and 'stakeholder engagement across marine protected areas focused on exchanges and developing dialogue mechanisms', representing 29 of the 52 stories. The latter theme was frequently connected to a further theme: 'dialogue mechanisms resulted in improved relationships and reciprocal access agreements between communities in marine protected areas' (six stories).

The development and management of the two administrative bodies (the Seascape Forum and Seascape Committee) enabled the seascape's implementing organizations (particularly NGOs) to put aside their own institutional agendas and share approaches. One NGO co-manager said that 'we realized all the partners had things in common and...working together we could achieve more', and another that 'relationships...within the network have improved, particularly [with] those who are not co-managers, who take a very different but valuable approach'. This increasingly collaborative atmosphere was not experienced by one organization ('there was no benefit to working with the other partners', although this same interviewee seemed to contradict this later in the same interview).

The fisher-focused collaborative body (the Fishers' Roundtable) seems to have provided an alternative to previous modes of community/NGO decision-making, such as 


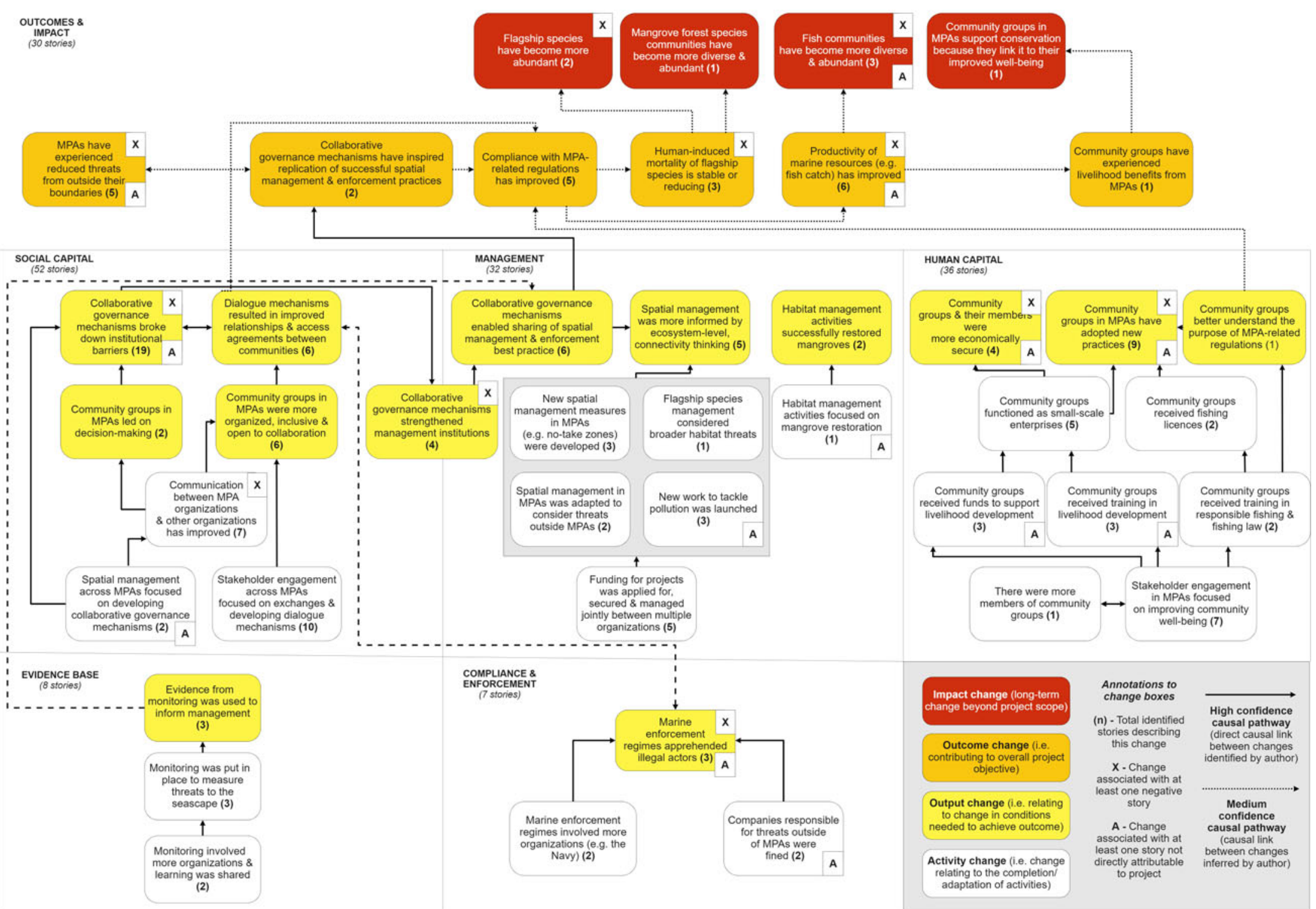

FIG. 3 Observed thematic changes, classified by change type and alignment with the project's theory of change at output level. 
TABLE 3 Dominant change themes drawn from interviews, ordered by change type.

\begin{tabular}{|c|c|c|c|}
\hline $\begin{array}{l}\text { Change } \\
\text { type }\end{array}$ & Change theme ${ }^{1}$ & $\begin{array}{l}\text { No. of stories representing } \\
\text { this theme }(\mathrm{Po}, \mathrm{At})^{2}\end{array}$ & $\begin{array}{l}\text { Intended project } \\
\text { output area }\end{array}$ \\
\hline \multirow[t]{3}{*}{ Outcome } & Productivity of marine resources (e.g. fish catch) has improved & $6(50,33)$ & Not applicable \\
\hline & Compliance with MPA-related regulations has improved & $5(100,100)$ & Not applicable \\
\hline & $\begin{array}{l}\text { MPAs have experienced reduced threats originating from outside } \\
\text { their boundaries }\end{array}$ & $5(40,40)$ & Not applicable \\
\hline \multirow[t]{6}{*}{ Output } & $\begin{array}{l}\text { Collaborative governance mechanisms broke down institutional } \\
\text { barriers }\end{array}$ & $19(95,89)$ & Social capital \\
\hline & Community groups in MPAs have adopted new practices & $9(67,89)$ & Human capital \\
\hline & $\begin{array}{l}\text { Collaborative governance mechanisms enabled sharing of spatial } \\
\text { management \& enforcement best practice }\end{array}$ & $6(100,100)$ & Management \\
\hline & $\begin{array}{l}\text { Community groups in MPAs were better organized, more inclusive } \\
\text { \& more open to collaboration }\end{array}$ & $6(100,100)$ & Social capital \\
\hline & $\begin{array}{l}\text { Dialogue mechanisms resulted in improved relationships \& } \\
\text { reciprocal access agreements between communities in MPAs }\end{array}$ & $6(100,100)$ & Social capital \\
\hline & $\begin{array}{l}\text { Spatial management was more informed by ecosystem-level } \\
\text { connectivity thinking }\end{array}$ & $5(100,100)$ & Management \\
\hline \multirow[t]{5}{*}{ Activity } & $\begin{array}{l}\text { Stakeholder engagement across MPAs focused on exchanges \& } \\
\text { developing dialogue mechanisms }\end{array}$ & $10(100,100)$ & Social capital \\
\hline & $\begin{array}{l}\text { Communication between MPA organizations \& other organizations } \\
\text { has improved }\end{array}$ & $7(71,100)$ & Social capital \\
\hline & $\begin{array}{l}\text { Stakeholder engagement in MPAs focused on improving commu- } \\
\text { nity well-being }\end{array}$ & $7(100,100)$ & Human capital \\
\hline & Community groups functioned as small-scale enterprises & $5(100,100)$ & Human capital \\
\hline & $\begin{array}{l}\text { Funding for projects was applied for, secured \& managed jointly } \\
\text { between multiple organizations }\end{array}$ & $5(100,100)$ & Management \\
\hline
\end{tabular}

${ }^{1}$ MPA, marine protected area.

${ }^{2} \mathrm{Po}$, per cent of stories representing this theme expressed as a positive change; At, per cent of stories representing this theme that could be wholly or partly attributed to the project.

one-to-one meetings between management entities and site-specific fisher organizations. The project's livelihoodsfocused NGO claimed that the novelty of having an entirely fisher-led body meant that initially it 'was questioned and nobody saw the point of it, since each fishing community already had a leader' but, once established, it gave fishers 'their own space to discuss their problems and [to] sit down with co-managers and representatives of local and national government to negotiate'. Significantly, such initiatives were linked, mostly by local government interviewees, to changes in reciprocal marine protected area use: 'fishers from Utila used to come and do dive fishing in Cuero y Salado and scare the fish away, whereas now there is an agreement that they use another space'. Fishers themselves from these two communities claimed they had gone from being 'enemies' into having 'a friendly relationship'.

\section{Human capital}

This output area (' 150 community members, who depend directly on the seascape, have enhanced human capital and are empowered to access and sustainably manage fisheries and strengthen economic enterprises'; Fauna \& Flora International, 2015, p. 25) aligned with $36(22 \%)$ of stories and was raised by 11 of 15 interviews (73\%). Stories aligned to this output were related to a variety of community groupfocused activities (e.g. training, inclusion in site management, awareness-raising) and the effects they had. The most prevalent themes were 'stakeholder engagement in marine protected areas focused on improving community well-being' and 'community groups in marine protected areas have adopted new practices', representing 16 of 36 stories. Activity-related changes in this area were around conservation training ('training in reforestation'), enterprise development training ('capacity building, focusing on food preparation, display and pricing'), awareness-raising ('workshops so that fishers would become more aware of the fishing regulations, necessary environmental licenses') and inclusion in marine protected area management ('we involved three community members in [our] conservation activities who had previously been turtle poachers').

Government and NGO interviewees involved in management claimed that this human-focused approach had largely been beneficial but were, in some cases, cautious. The comanager who described the involvement of former turtle poachers claimed this 'was an innovative and experimental way of working' but also noted that 'there are risks to this approach'. Another claimed this approach had led to 'a strong relationship with a difficult to access community... who originally perceived them as an enforcement organization'. 
Although community groups flagged that their material well-being has improved in the short-term as a result of some of these activities ('we have an increased understanding of economic principles...which in turn has led to greater income from these endeavours'), these stories were more commonly linked to longer-term trends towards better relationships with co-managers (the 'relationship with [comanager] was initially very poor, but has improved over the past decade and we now receive a lot of support from [co-manager]') and more responsible practices ('the problem with the nets is improving, because although they are still used, they are not used as much as they were in the past').

\section{Management}

This output area ('Across the seascape, management of key fisheries, habitats and species are strengthened through coordinated planning and action'; Fauna \& Flora International, 2015 , p. 20) aligned with 32 (19\%) of stories and was raised by 9 of 15 interviews $(60 \%)$. Stories aligned to this output were related to specific management activities (e.g. spatial management planning/zonation, habitat restoration, species management, fundraising) and how these ongoing activities had been influenced by the project. The most prevalent themes were 'collaborative governance mechanisms enabled sharing of spatial management and enforcement best practice', 'funding for projects was applied for, secured and managed jointly between multiple organizations' and 'spatial management was more informed by ecosystem-level, connectivity thinking', representing 16 of 32 stories.

Many of these stories were about management institutions learning from one another and adapting as a result. One NGO co-manager claimed they had started 'to focus efforts on their own iguana species' after hearing about the experiences of another organization; a second NGO comanager claimed that the 'first no-take zones [i.e. areas of strict spatial closure within designated sites] established around Utila in 2018 have become more organized. . .learning from experiences in Cayos Cochinos'. Enhanced collaboration also enabled pooled financial resources ('[we] help each other cover costs for workshops' and '[we] invested match funding into project activities in order to achieve more impact').

Finally, this management network seems to have also broadened interviewees' perspectives on the Atlántida seascape and enabled more seascape/connectivity thinking. One local government interviewee explained that 'we have the same ecosystems and the same problems. And we have fishers who move between these areas...species do not have limits'. An NGO co-manager claimed that a key change was that all bodies involved in management 'better understand that an ecosystem is an integrated, connected and complex system, and that habitats and species are interlinked and dependent on each other'.

\section{Marine evidence}

This output area ('Evidence base for marine conservation and sustainable fisheries management is strengthened, through research and seascape-wide sharing of scientific and traditional knowledge, and is informing seascape management', ibid., p. 22) aligned with 8 (5\%) of stories and was raised by 5 of 15 interviews (33\%). These stories yielded three themes: 'monitoring was put in place to measure threats to the seascape', 'monitoring involved more organizations and learning was shared' and 'evidence from monitoring was used to inform management'. In these stories, interviewees described how the project had helped to 'gather baseline data' and 'obtain better quality data'. Both NGO and academic interviewees highlighted that 'the partner network was very important in enabling this' and that they even 'created a common database... encouraging all of the partners to share their individual datasets'. One NGO co-manager commented that such data were used 'for establishing appropriate management, zonation and monitoring plans'.

\section{Compliance and enforcement}

This output area ('Across the seascape, there is increased compliance with regulations and enforcement capacity is enhanced', ibid., p. 22) aligned with only 7 stories (4\%) and was mentioned in 4 of 15 interviews (27\%), although there were some overlaps with the management output area. These stories yielded three themes: 'marine enforcement regimes involved more organizations (e.g. the Navy)', 'companies responsible for threats outside of marine protected areas were fined' and 'marine enforcement regimes apprehended illegal actors'.

One fisher highlighted better connections between comanagers and higher-level enforcement entities, claiming they are now 'very vigilant with no-take zones. . . if someone comes to fish, they call the navy'. A local government interviewee claimed their own enforcement efforts in overcoming (supposedly) licensed industrial trawling vessels had been bolstered by naval support, saying that 'even in cases when fishers have a permit to trawl, the marines have taken them away'. Although this visible increase in capacity was welcomed, there were less positive stories about letting arrested fishers 'go with all of their gear, so they go back to fishing illegally' and that this was because they were 'wellconnected and can therefore pull strings to be released'.

\section{Changes related to project outcome and longer-term impact}

Although stories expressed as activities and outputs were more common, 30 stories (18\%) relayed by 12 interviewees $(80 \%)$ alluded to broad achievement of the project's outcome and longer-term impact. The most prevalent outcome 
themes were 'productivity of marine resources (e.g. fish catch) has improved' and 'compliance with site-related regulations has improved', representing 11 of 30 stories. Impact themes were represented by only 7 stories, and included 'fish communities have become more diverse and abundant' (3), 'flagship species have become more abundant' (2), 'community groups in marine protected areas support conservation because they link it to their improved well-being' (1) and 'mangrove forest species communities have become more diverse and abundant' (1). Compared to other themes, these themes had higher proportions of stories that could not be solely or partly attributed to the project itself and were, in some cases, reflective of longer-term trends (Table 3).

Outcome level changes focused on recent or longer-term changes in fishery productivity, with fishers, in particular, claiming that 'the fish banks are reproducing more' (referring to no-take zones), 'improve[ments in] the quantity of shrimp in the sea' and this being 'reinforced by other fishers wanting to come to fish in the richer waters'. This was repeatedly linked to reductions in damaging practices (e.g. 'a reduction in spearfishing and therefore bycatch of parrotfish'), driven by the fact that fishers 'respect...closures' as they 'have a better understanding of why they are in place'.

Fishers were again the interviewees most likely to identify impact level changes, especially those focused on biodiversity recovery, including that 'local fishers have noticed the return of some fish since implementing some protection' but that this was set against the need to overcome a longerterm decline ('since childhood, fish communities have decreased in diversity and density'). Similarly with flagship species, community groups described how 'the protected area has increased the number of birds, iguanas, deer' and that although 'I remember my grandfather and uncles used to hunt and eat manatee, [co-manager] and fishers protect the manatee now and I have noticed manatee juvenile numbers increasing'.

Finally, one NGO co-manager provided the most compelling interview evidence (attributed to the project) of the reciprocal impacts of marine protected areas delivering improved biodiversity and benefits to people: '[the] community recognize[s] the importance of sustainable fisheries and their support with protection efforts because they can perceive the positive impacts'.

\section{Discussion}

This study has shown that in the Atlántida seascape in Honduras (and the 4-year project supporting it), enhanced social capital was the category of significant change most consistently identified by a range of interviewees, from seascape users to managers. The study's interview evidence suggests the activities and outputs of the evaluated project have contributed to groups of actors involved in the seascape functioning as a social network, operating through a suite of collaborative governance mechanisms. This finding supports the theory that conservation success in complex, cross-boundary initiatives depends on the strength and proliferation of connections in a collaborative network (Kark et al., 2015).

Enhanced collaboration and social networking in the seascape has encouraged a culture of learning and knowledge exchange as well as active sharing of resources, funding and strategies, particularly between marine protected area managers. This operational collaboration has enhanced effective replication of interventions, e.g. species protections being reproduced from one site to another or implementation of new no-take zones benefitting from learning about their placement and management from a seascape peer. Similar instances of established marine conservation practices and interventions being diffused through sociallyconnected collaborations have been observed in Kenya (Mbaru \& Barnes, 2017), Tanzania (Mascia \& Mills, 2018) and the Solomon Islands (Cohen et al., 2012).

In line with the intention of the seascape model, the study found that multi-level governance institutions were perceived as having resolved long-standing, intercommunity fishery resource conflicts, particularly between communities living in one site and fishing in another. Berkes (2009, p. 1695) highlights the role of 'bridging organizations [that] provide an arena for...trust building. . . and conflict resolution', citing national and regional examples from Canada, Sweden and the Philippines. The Atlántida seascape, as a regional bridging organization, seems to have provided a mechanism for the stakeholders representing individual marine protected area to address problems collectively, thereby increasing the effectiveness of spatial intervention measures at a single-site level (i.e. zonation, compliance, access).

Improved human capital was the second most frequently identified change in the study, particularly around small-scale enterprise development, inclusion in management and the resulting changes in relationships between the marine protected area manager and the community. Although protected areas in Honduras are, in theory, built around a co-management framework, the application of this model in seascape marine protected areas has been noted as delivering management practices that were either collaborative only in theory or that 'tipped the scales too far away from conservation' (Bown et al., 2013, p. i). The evidence in our study suggests that, although some managers may still be wary of the risks of genuinely inclusive management practices, all sites are now more legitimately co-managed. The preference of community-based interviewees to focus on changes in their relational well-being (i.e. having stronger relationships and connections, particularly to decision makers) and to link these to changes in their behaviour 
(as opposed to relating them to changes in enforcement practice) suggests that seascape marine protected areas are now governed with a much greater focus on 'legitimacybased motivations' around compliance in small-scale resource use systems (Oyanedel et al., 2020, p. 1).

Perceived changes associated with the seascape project's overall outcome and longer-term intended impact ("protecting critical habitats and species, making fisheries more sustainable, and improving livelihoods and food security', Fauna \& Flora International, 2015, p. 18) were less frequently observed, in line with a previous review of large-scale, multisite marine management regimes that claimed such 'third order outcomes are often more likely to be site- or species specific' (Bensted-Smith \& Kirkman, 2010, p. iii). In this study, evidence was collected of perceived long-term ecological recovery and related improvements in human well-being (especially around increased fish abundance and diversity), mostly attributed to both this project and long-standing interventions; e.g. existing no-take zones, and decade-long cycles of more collaborative, inclusive stakeholder engagement. These findings tentatively link seascapes to recent related research around the effectiveness of appropriately-scaled, ecosystembased, collaboratively-governed marine management that balances strict protection with sustainable use (Bobiles \& Nakamura, 2019; Campbell et al., 2020; Gilchrist et al., 2020).

Acknowledgements I thank the Darwin Initiative and Arcadia, a charitable fund of Lisbet Rausing and Peter Baldwin, for their support for the Honduras seascape project, all interview participants, especially those from the five Honduran partner NGOs (Jimmy Andino, Ivany Argueta, Marcio Arrone, Geyvy Delarca, Marcio Rivera and Gerardo Yanes), Alina Maria Amaya Zelaya for translation, and FFI colleagues who helped organize the evaluation (especially Quentin Marchais), analyse interview data (Hazel Akester, Gabriella Church and Nicola Sorsby) and check the text (Sue Wells).

Conflicts of interest The author is employed by the organization implementing the project being evaluated, but does not play any role in co-ordinating or managing the project and can therefore be considered semi-independent from its implementation.

Ethical standards Participants were asked to give their consent to be interviewed and for the analysis of the data arising from the interviews (see Supplementary Material 2 for the full opening statement read to all interviewees). All interviewee consents were video recorded. The study results from a project focused on investing in the capacity of Honduran NGOs and the results represent the impact of their work. Key individuals from these organizations reviewed the manuscript. This work otherwise abided by the Oryx guidelines on ethical standards.

\section{References}

Armborst, A. (2017) Thematic proximity in content analysis. Sage Open, 7, 1-11.

Bensted-Smith, R. \& Kirkman, H. (2010) Comparison of Approaches to Management of Large Marine Areas. Fauna \& Flora International, Cambridge, UK.
BERKES, F. (2009) Evolution of co-management: role of knowledge generation, bridging organizations and social learning. Journal of Environmental Management, 90, 1692-1702.

Bobiles, R.U. \& Nakamura, Y. (2019) Partially protected marine areas as a conservation tool for commercially important fishes in the Philippines: do age, size, and design matter? Regional Studies in Marine Science, 25, 100459.

Bown, N., Gray, T.S. \& STEAD, S.M (2013) Contested Forms of Governance in Marine Protected Areas: A Study of Co-Management and Adaptive Co-Management. Routledge, New York, USA.

Campbell, S.J., Darling, E.S., Pardede, S., Ahmadia, G., Mangubhai, S. \& Maire, E. (2020) Fishing restrictions and remoteness deliver conservation outcomes for Indonesia's coral reef fisheries. Conservation Letters, 13, e12698.

Chambers, R. (2009) So that the poor count more: using participatory methods for impact evaluation. Journal of Development Effectiveness, 1, 243-246.

Cohen, P.J., Evans, L.S. \& Mills, M. (2012) Social networks supporting governance of coastal ecosystems in Solomon Islands. Conservation Letters, 5, 376-386.

Davies, R.J. \& DART, J. (2005) The "Most Significant Change" (MSC) Technique: A Guide to its Use. Davies and Dart, Cambridge, UK.

Dearden, P., Bennett, M. \& Johnston, J. (2005) Trends in global protected area governance, 1992-2002. Environmental Management, 36, 89-100.

De SAnto, E.M. (2013) Missing marine protected area (MPA) targets: how the push for quantity over quality undermines sustainability and social justice. Journal of Environmental Management, $124,137-146$.

Fauna \& Flora International (2015) Connecting Coastal Communities for Integrated Seascape Management in Atlántida, Honduras (Project 23-028). Darwin Initiative Application for Grant for Round 22. darwininitiative.org.uk/documents/DAR23028/ 23643/23-028\%20App\%2orev\%2oMar16\%20-\%2oedited.pdf [accessed 22 October 2020].

Foley, J.R. (2012) Managed access: moving towards collaborative fisheries sustainability in Belize. In Proceedings of the 12th International Coral Reef Symposium (eds D. Yellowlees \& T.P. Hughes). James Cook University, Townsville, Australia.

Gibis, G.R. (2007) Thematic coding and categorizing. Analyzing Qualitative Data, 703, 38-56.

Gilchrist, H., Rocliffe, S., Anderson, L.G. \& Gough, C.L. (2020) Reef fish biomass recovery within community-managed no take zones. Ocean \& Coastal Management, 192, 105210.

Gill, D.A., Mascia, M.B., Ahmadia, G.N., Glew, L., Lester, S.E., Barnes, M. \& Holst, S. (2017) Capacity shortfalls hinder the performance of marine protected areas globally. Nature, 543 , 665-669.

Grorud-Colvert, K., Claudet, J., Tissot, B.N., Caselle, J.E., CARR, M.H., DAY, J.C. \& WALSH, W.J. (2014) Marine protected area networks: assessing whether the whole is greater than the sum of its parts. PLOS ONE, 9, e1O2298.

Jouffray, J.B., Blasiak, R., Norström, A.V., Österblom, H. \& NyströM, M. (2020) The blue acceleration: the trajectory of human expansion into the ocean. One Earth, 2, 43-54.

Kapos, V., Balmford, A., Aveling, R., Bubb, P., Carey, P., Entwistle, A. \& Walpole, M. (2009) Outcomes, not implementation, predict conservation success. Oryx, 43, 336-342.

Kark, S., Tulloch, A., Gordon, A., Mazor, T., Bunnefeld, N. \& Levin, N. (2015) Cross-boundary collaboration: key to the conservation puzzle. Current Opinion in Environmental Sustainability, 12, 12-24.

Kossmann, C.M., Behagel, J.H. \& Bailey, M. (2016) Action and inertia in collaborative governance. Marine Policy, 72, 21-30. 
Kraft, K. \& PrytherCh, H. (2016) Most significant change in conflict settings: staff development through monitoring and evaluation. Development in Practice, 26, 27-37.

Lester, S.E., Costello, C., Halpern, B.S., Gaines, S.D., White, C. \& BARTH, J.A. (2013) Evaluating tradeoffs among ecosystem services to inform marine spatial planning. Marine Policy, $38,80-89$.

LoperenA, C.A. (2016) Conservation by racialized dispossession: the making of an eco-destination on Honduras's North Coast. Geoforum, 69, 184-193.

Mascia, M.B. \& Mills, M. (2018) When conservation goes viral: the diffusion of innovative biodiversity conservation policies and practices. Conservation Letters, 11, e12442.

Mbaru, E.K. \& Barnes, M.L. (2017) Key players in conservation diffusion: using social network analysis to identify critical injection points. Biological Conservation, 210, 222-232.

Oyanedel, R., Gelcich, S. \& Milner-Gulland, E.J. (2020) Motivations for (non-) compliance with conservation rules by small-scale resource users. Conservation Letters, 13, e12725.

Rabie, B. \& Burger, A. (2019). Benefits of transport subsidisation: comparing findings from a customer perception survey and most significant change technique interviews. African Evaluation Journal, 7, 7 .

Reason, P. \& Bradbury, H. (eds) (2008) The SAGE Handbook of Action Research. 2nd edition. SAGE, London, UK.

Solandt, J.L., Jones, P., Duval-Diop, D., Kleiven, A.R. \& Frangoudes, K. (2014) Governance challenges in scaling up from individual MPAs to MPA networks. Aquatic Conservation: Marine and Freshwater Ecosystems, 24, 145-152.

Sutton, J. \& Austin, Z. (2015) Qualitative research: data collection, analysis, and management. The Canadian Journal of Hospital Pharmacy, 68, 226-231.

Waylen, K.A., Fischer, A., McGowan, P.J., Thirgood, S.J. \& Milner-Gulland, E.J. (2010) Effect of local cultural context on the success of community-based conservation interventions. Conservation Biology, 24, 1119-1129.

Wilder, L. \& Walpole, M. (2008) Measuring social impacts in conservation: experience of using the most significant change method. Oryx, 42, 529-538.

Woodhouse, E., De Lange, E. \& Milner-Gulland, E.J. (2016) Evaluating the Impacts of Conservation Interventions on Human Wellbeing. Guidance for practitioners. IIED, London, UK. 